\title{
Karikatür Sanatının Görsel Sanat Disiplinlerindeki Temsilleri
}

\section{Özet}

Karikatür sanatı, grafiksel ve çizgisel bir ifade biçimi olarak yüzyıllar boyunca içerik ve görünüm açısından değişim göstermiştir. Bu gelişim sürecinde farklı sanat dallarından etkilenmekle birlikte bir anlatım tarzı haline gelerek, pek çok sanat dalını da bu yönde etkilemiştir. Böylece anlatım dili giderek zenginleşen bu mizahi iletişim şekli, hacimsel ve devinimsel özelliklerdeki farklı sanat disiplinlerinde de kendini göstermeye devam etmektedir.20. Yüzyılda sanat disiplinleri arasında görülen etkileşimler, yeni anlatım biçimlerini doğurmuş ve sanat dalları arasında fikir ve biçim açııından karşılıklı beslenme yeni anlatım biçımlerini doğurmuş ve sanat dalları arasında fikir ve biçım açısından karşılıkl beslenme bir sanat dalı olarak kabul gören karikatür, birçok ifade aracı ve iletişim mecrasında böylece kendine yer bulmuştur. Araştırma dâhilinde resim, heykel, fotoğraf, tiyatro, seramik ve sinema alanlarında görülen karikatür yorumları ve formları inceleme altına alınmıştır.

Anahtar Kelimeler: Mizah, Karikatür, Grafik,Görsel Sanatlar, Çizgi

\section{REPRESENTATIONS OF CARICATURE ART IN VISUAL ART DISCIPLINES}

\section{Abstract}

Cartoon, as a graphic and linear form of expression has changed over the centuries in terms of content and appearance. In this development process, it was influenced by different branches of art, it became $a$ style of expression and affected many branches of art in this direction. Thus, this humorous communication style, and its, language of expression is getting richer, continues to manifest itself in different art disciplines with volumetric and dynamic features. The interactions between art disciplines in the 20th century gave birth to new forms of expression and provided opportunity for mutual nourishment between art branches in terms of ideas and forms. Caricature, which is not only a product of print and broadcasting, but is accepted as an art branch, has found a which is not only a product of print and broadcasting, but is accepted as an art branch, has found a were examined seen in fields such as painting, sculpture, photography, theater, ceramics and cinema.

Keywords:: Humor, Caricature, Graphic, Visual Arts, Line 


\section{Giriş}

Karikatür, insanların, varlıkların, olayların hatta duygu ve düşüncelerin doğala ters düşen, olağanla çelişen gülünç yanlarını yakalayıp yazılı veya yazısız olarak, abartılı çizimlerle gülmece anlatımına dönüştürme sanatı olarak tanımlanmaktadır (Özer, 1997: 51). Karikatürist ise sanatını oluştururken gözlemlediği olayları, düşünceleri ve yorumları kendi açısından algılayarak bunlardan birer simge yaratmakta ve bu simgeleri güldürü yaklaşımı ile nükteli çizgilere dönüştürmektedir (Kurultay ve Peksevgen, 2015: 154). Bu doğrultuda karikatür, yaşamın güncel, tarihsel ve geleceğine ilişkin tüm alanlarını haber, ileti ve bilgi özeti haline getirirken sanat olma savını sürdüren bir iletişim dalı olarak şekillenmiştir(Oral, 1998: 10).

Resimden yola çıkan karikatür, başlangıçta insanların yüzlerini, görünüşlerini bozma, abartma, karakteristik özelliklerini ön plana çıkartma olarak değerlendirilmiştir (Fidan, 2007: 39).Genel olarak karikatür, yüzün ya da orantısız vücudun tipik özelliklerini abartan, biçimini bozan gülünç çizim ya da resim olarak tanımlanmaktadır. Karikatür durağan bir araç olarak resim ve fotoğrafa yakındır ve iki temel öğe olarak kompozisyon ve simgeciliğ içinde barındırmaktadır. Kurgu düzenini, resimsel sunumla harmanlayarak gerçeği yeniden gözler önüne sermekte ve yaratmaktadır (Jovanovic, 1997: 27). Abidin Dino (1913-1993), karikatürde varolan bu içeriksel ve biçimsel yaklaşımın kaynağını şöyle açıklamıştır: "Karikatür, dünyada ve ülkemizde burjuvazinin kendi kendini eleştirme gereksinmesinden ortaya çıkmış sayılabilir. Yani burjuvazi, güzeli aşırı derecede överken, aynı zamanda çirkini de diyalektik bir biçimde ortaya çıkarma ihtiyacı duymuştur" (Demirel, 2007: 218)

Adolph Appia çizgiyi, süreçle boyutun buluşması olarak tanımlamıştır. Çizginin oluşabilmesi için yer ve zaman etmenleri gereklidir. Her karikatürün içinde, mutlaka çizginin oynadığı belirli bir rol, süreç ve düzey vardır. Seyircinin gözü, karikatüristin çizgisini okurken, üretim aşamasındaki aynı dolaşımı yaparak tekrarlamaktadır (Demirel, 2007: 209-210). Ancak karikatür, salt bir çizim değildir. Bir diğer bileşene de değinmek gerekirse karikatür, çizgiler aracılığıyla zihindeki imge tasarımı ve düşüncelerin dışavurumudur. Bu yönüyle yeni anlam, çă̆rışım olanakları, tasarım ve gerçeklikler sunmak durumundadır (Efe, 2007: 99). Güçlü bir çizgi, anlatılmak isteneni kısa yoldan, en etkin biçimde izleyene ulaştırmalıdır. Kişiliği olan güçlü bir desen, sanatçının anlatım olanağına geniş bir alan sağlar. "Karikatürcünün biçemini bulması, çizgisini bulmasılyla başlar" (Çeviker, 1997: 351). Saul Steinberg (1914-1999)'e göre her çizim sanatçıyı yeniden oluşturur. "Ogni dipintore dipingese" bir Rönesans deyişidir ve "Her ressam kendini çizer." anlamına gelmektedir. Steinberg buna katılarak, "çizdikleri, sanatçının kendi maskesidir" demiştir (Oral, 1998: 334).Renk, karikatürde esas değildir. Ancak çizgi temel etmendir. Çizgi, karikatürün özü olarak dışarıdan bir etkiye uğradığı anda amaçlanan iletinin değişimine yol açmaktadır (Senyapılı, 2003: 68). Karikatür sanatında, iletiyi çizgiyle aktarmak, bu eylemi yaparken de düşünceden ve düş gücünden yararlanılan soyutlamayla, somut bir duruma vurgu yapmak söz konusudur. Çizgi ile mizah yapmak, aslında çizgi ile düşünmek, anlatmak, düşündürmek ve dikkat çekmektir (Saydut, 2010: 59-78).Karikatür, ironik düşünmenin kapılarını açabilir. İroninin katıldığı kırıcı, alışılagelen düşünme biçimlerini askıya alıcı gücü, çizgiye aktarılabildiğinde karikatür varlık veyaşanan hayat üzerine çizgiyle yapılan bir felsefe haline gelir(Inam, 2010: 3).

Karikatür, anlatım aracı olarak genellikle abartılmış biçim deformasyonları içeren çizimler kullanmaktadır. Gerçekliğin ilgili yanlarını abartma, ilgisiz yanlarını ise yalınlaştırma ya da bir yana atma tekniği, sanatçıyla karikatürcüyü aynı noktada toplayan bir özelliktir (Koestler, 1997: 9). Geometrik orantılar sanat eserinde geçerli olurlar. Örneğin; bir dikdörtgenle, bu dikdörtgenin eni ölçülerinde bir kare arasındaki orantı buna örnek teşkil edebilir. Ancak geometrik orantıların bir sanat eserinde kusursuz gerçekleşmesi bir cansızlık da yaratabilir. Bu yüzden karikatürde kasti bozmalar, eseri çok daha çekici kılabilmektedir (Poroy, 1997: 37).

Gelişen teknoloji ve yaşam şartları, farklı mizah çeşitlerinin ortaya çıkmasını sağlamıştır. Basının gündelik yaşamda yerini almasıyla insanlar yazılı mizahla tanışmış ve sözlü mizah ikinci planda kalmıştır (Yardımcı, 2010: 1). Basın yayın organlarında kendini gösteren karikatür ise çağımızda etkin olan bir mizah türü haline gelmiştir. "Önceleri sadece kişilerin portreleriyle ilgilenirken daha sonra olayları ve sosyal konuları ele almış, bu gelişmeler sırasında çizgi anlayışı ve teknik açıdan da değişimler göstermiştir" (Özer, 2004: 246).Karikatür, kişilerin, nesnelerin ve olayların gülmeye ya da gülümsemeye yol açacak bir biçimde temsil edilmesi özelliğiyle resimsel ve gülmeceli bir görsel ileti işlevi içerisindedir. Yazınsal birer metin olan öykü, roman, deneme, fıkra ile görsel bir metin olan karikatür kendi yapısal işleyişleriyle farklı yollar alıyor gibi görünseler de biçim ve içerik olarak güncel olandan etkilenmektedirler. Bu sanat ürünlerinin güncelliğini belirleyen etkenler, içinde bulunduğu ortamın sosyal, siyasal, ekonomik ve tarihsel nedenleridir. Bu sanat ürünlerinin işlevsel konularını belirlerken; uzamsal işlerliği, güzel duyu ve estetik beğeniyle yoğurulmaktadır. Karikatür ve yazınsal türlerdeki temasal işlerliğin estetik bir boyutu da uzamsal örgüde eritilmiştir (Efe, 2013: 38). Tarihsel gelişimi içerisinde ise biçimlerine ve kullanım alanlarına göre karikatür, türlere ayrılmıştır. Bu türler, hem çizerlerin 
olaylara veya kişilere karşı alaycı yaklaşımlarındaki farklılıklar hem de biçem ve sunum tercihleri açısından doğmuştur. Bu çeşitlilik sayesinde karikatür sanatının dili zenginleşmiş ve farklı iletişim kanallarında aktifleşmeye başlamıştır.

Karikatürün oyunsu ve estetik biçemi, onun farklı sanat dalları ile görsel, sözel ve yazınsal bağlar kurmasına olanak sağlamıştır. Mizahın bir alt kolu olarak, diğer mizah çeşitlerini hem beslemiş hem de onlardan beslenmiştir. Karikatürize etmek veya karikatürlesmek deyimleri, görsel, yazınsal ve devinimsel sanat dallarında bir terim olarak kullanılmakta ve karikatür anlatımını zenginleştirmektedir. Temelleri güldürü ve eleştiri üzerine kurulu olan bu sanat dalında da kimi zaman eğlence kimi zaman eleştiri ağır basmaktadır. Dolayısıyla bu yönelimlere göre teknik ve içerik açısından türlere, tarzlara ayrılmış olankarikatür sanatının tarihsel gelişim sürecinde farklı alanlara etkileri de bu çeşitlilikten ileri gelmiştir.

Sanat, kullandığı biçimleme araçları ve kullandığı yöntemler sonucunda varmak istediği amaca göre dallara ayrılmaktadır. Aynı zamanda farklı sanat dalları birbirleri ile ilişki içinde kalmaya devam etmektedir. Her sanat dalı, basska bir sanat dalından destek alabilmektedir (Coşar, 2010: 697). Dramatik Sanatlar; göze ve kulağa hitap eden, zaman ve mekân boyutu ile ortaya çıkan sanatlardır (tiyatro, opera, bale, dans). Fonetik (Kinetik) Sanatlar; sese ve söze biçim veren sanatlardır (edebiyat, müzik). Plastik (Görsel) Sanatlar ise maddeye biçim veren sanatlardır (heykel, resim, seramik, grafik, çizgi film) (Yardımcı, 2010: 28). Bu sanat dalları içerisinde esnek anlatım biçimleri ve çizgisel diline sahip olan karikatür, farklı formlarda kendini gösterebilmektedir. Pratik bir şekilde ilgi odağı oluşturmayı başarması hızla kitleselleşmesi, toplumsal işlevi ve kavradığı sorunları geleceğe dönük olarak yorumlama becerisi, karikatürün öteki sanatlarla karmaşık bir ilişki içinde olduğunun göstergesidir (Acar, 1979: 11). Bu özelliklerinin katkısıyla karikatür sanatı, gazete ve dergilerle sınırlı kalmayarak, çizgi romanda, eğitim malzemelerinde, duvar resimlemelerinde, televizyonda animasyon olarak, baskılı malzemelerde ve süslemelerde kullanılarak varlığını sürdürmektedir (Fidan, 2007: 43). Farklı sanat disiplinleri içerisindeki üretimler ve ifade biçimlerindeki karikatür çizgileri ve anlatılarının örneklendirileceğ araştırmanın bölümlemesi, resim-grafik, fotoğrafçılık, sahne sanatları, heykel ve sinema şeklinde yapılmıştır.

\section{Resim ve Grafik}

Çizgi, karikatürün tanımı itibariyle önemli bir dayanak ve temel biçimlendirme elemanıdır. Karikatürün çizgiye dayalı, çizgiyle oluşturulan yapısı onu grafik sanatlara yaklaştırmaktadır (Şenyapılı, 2000: 3). Grafik sanatının kollarından birisi olarak gösterilen karikatür, bu nedenle semantik ve estetik olarak incelenmektedir. Semantik yanı düşünce ve içeriği temsil ederken estetik yanı ise görsel iletinin sanatsal yanını oluşturmaktadır (Özer, 2004: 246). Grafik araçlar yardımıyla, genellikle desenle ifade edilmiş bir mesajın iletilmesi söz konusudur. 20. yüzyıldaki modern karikatür anlayışında yaz kullanımından kısmi olarak vazgeçildiğive "humour graphique" olarak tanımlanan örneklerortaya çıkmıştır. Özellikle Saul Steinberg'in 1945'te yayımladığı albüm olan All in Line (Yalnız Çizgiyle), dünya karikatür sanatında yeni bir anlayışın başlangıcı olmuştur. 1946'da New York'da açtığı sergiyle sanatını bütün dünyaya tanıtmıştır. Steinberg'in etkisi Avrupa'da hemen kendisini göstermiş ve Fransa'da Chaval, Sine, Bosc, Mose, André Rouveyre İngiltere'de Emett, Ronald Searle ve Almanya'da Paul Flora başta olmak üzere pek çok sanatçıya ilham kaynağı olmuştur. Steinberg'in yayınladığı albümle karikatür sanatında çizgide ekonomi anlayışı var olmuştur (Selçuk, 1998: 38-39). Bu anlayış; çizimlerdeki figür, nesne ve mekânlarda her türlü ayrıntı, gölge ve süslemelerin dışarda bırakılmasıyla oluşmaktadır. Bu yalın görselliğe uygun olarak alt yazıdan tümüyle vazgeçilmiş ve anlatım arac olarak sadece çizgiye önem verilmiştir. Grafik mizah, artık salt çizgiden oluşan bir yalınlığa indirgenmiş̧tir (Sipahioğlu, 1999: 110)

Türkiye'de 50 Kuşağı'nın önde gelen çizerlerinden Turhan Selçuk (19222010), bu tanımı Türkçe'ye "grafik mizah" olarak çevirmiştir (Selçuk, 1998: 151). Bu tanımlama grafik sanatı ile karikatürü bir yandan bütünlerken, karikatür ile mizahi illüstrasyon ayrımını da gündeme getirmiştir. Mizahi illüstrasyon ile karikatür arasındaki fark, bu alanların her ikisinde de eserler veren sanatçıların etkisiyle tam olarak belirginleşememektedir. Özellikle bilgisayar teknolojisinin ve uygulamalarının yaygınlaşması ile birlikte karikatür yeni bir boyut kazanmış, karikatüristler de farklı arayışlara yönelmişlerdir. Karikatür-grafik ilişkisi artmış, dijital eserlerin illüstrasyon, grafik ya da karikatür olarak doğrudan isimlendirilmesi ya da bir ayrımın yapılabilmesi güçleşmiştir (Uçan, 2013: 49). Örneğin; Jan Lenica (19282001) (Görsel 1), Tomi Ungerer (1931-2019), André Rouveyre (18791962), Ralph Steadman ve Aubrey Hammond (1893-1940) grafik tasarım alanında gerçekleștirdikleri afiş ve illüstrasyon çalışmalarına karikatürize yorum katmış önde gelen sanatçılardandır. 


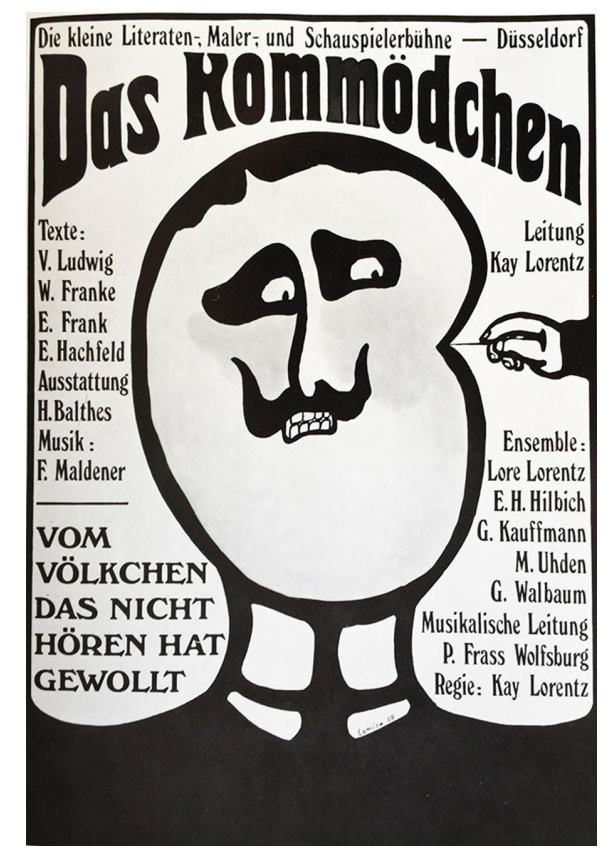

Görsel I. Jan Lenica, 'Das Kommödchen' Kabare Poster Tasarımı (1969)'

Werner Hofmann modern sanat ile karikatürün iki yaklaşımda benzeştiğini öne sürmüştür. Bunlar, çizgilerle basitliğe gitmek ve mutlak güzelliği değil, gerçekliği aramak olarak tanımlanabilir. Karikatürcü, biçimi daima basitlestirmeye çalışmıştır. Modern ressamların da aynı yolu izlediği görülmektedir (Topuz, 1986: 23). Modern sanattan önceki devirlerde de karikatürün resim sanatıyla ayrılmaz bir bağı olmuştur. Abartma, parodi, alay, mizah ve konuşma balonları gibi karikatürün özellikleri, aralarında Honore Daumier, William Hogarth, Rodolphe Töpffer, Henri de Toulouse-Lautrec, Francisco Goya, George Grosz, Paul Klee, Joan Miro ve Pablo Picasso'nun da bulunduğu çok sayıda ünlü sanatçının yapıtlarında görülmektedir. Bu sanatçılar, bazı eserlerinde karikatür tiplerini ve görüntülerini yapıtları için kaynak olarak kullanmış ve süreç içinde bunları resme dönüştürmüşlerdir (Şenyapılı, 2000: 22). "Karikatürsel betimleme baska idealar ve simgelerin kaynaklar ile birlikte tuvallere girmiştir. Ancak karikatürsel betimleme beraberinde bir tarih, toplumsal kurgulama ve popüler anlayış taşımaktadır." Andy Warhol, Roy Lichtenstein ve Philip Guston gibi sanatçılar belli bir karakteri yalıtmak

I https://visualdiplomacyusa.blogspot.com/2018/ I //artist-of-day-november-6-jan-lenica.html ya da bir imgeyi karikatürcü gibi ama çok ciddi bir niyetle aktarmak için karikatürize betimlemeyi kullanmışır. Bu örnekler dâhilinde karikatür; güzel sanatlara dış dünyaya gönderme yapmayı, onunla oynamayı, bir sanat yapıtındaki niyetlerle alay etmeyi, şakalaşmayı ve maskelemeyi sağlamıştır (Şenyapılı, 2003: 72-73).Bu alanda ön plana çıkan Türk çizerlerden Selçuk Demirel ve Gürbüz Doğan Ekşioğlu (Görsel 2) da karikatürde çizginin yanına renk ve doku elemanlarını da katarak karikatüre plastik boyut kazandırmıs ve karikatürün resimsel niteliklerini vurgulamıslardır (Girgin, 1985: 92). Sanatın bireşimler çağında bu çizerlerin eserleri, karikatür, resimleme, grafik ve kolaj türlerini tek karede bütünlesstirerek geniş bir algıya hitap etmiştir. Çizerlerin bu yaklaşımı, karikatür sanatını belirli kalıplara sokmadan, eserlerini istedikleri disiplin içerisinde tanımlama özgürlüklerini açı̆̆a çıkarmıştır.

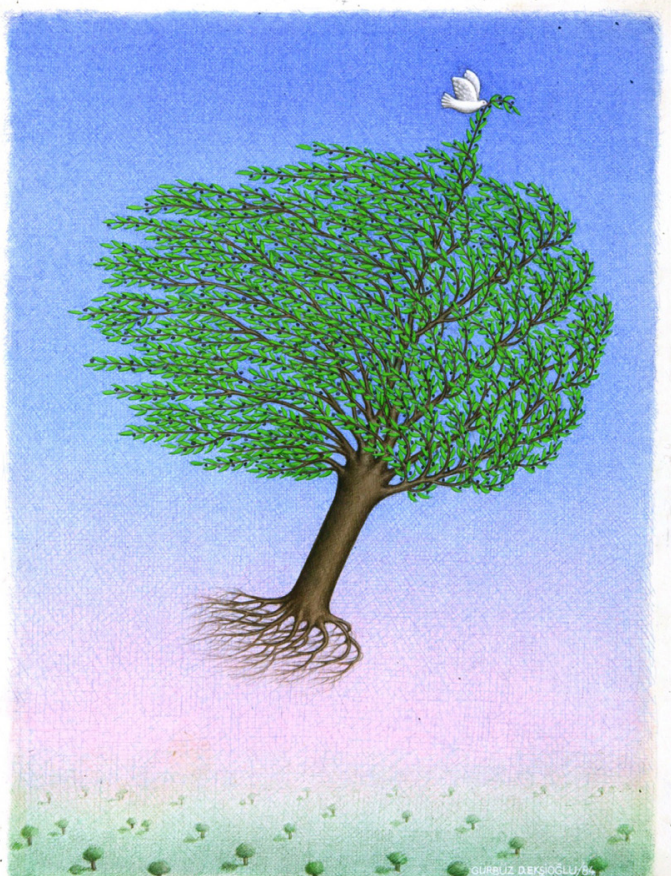

Görsel 2. Gürbüz Doğan Ekşioğlu, 'Dünya Barışı’ karikatürü, 1984 (Koloğlu, 2005: 362).

Türkiye'nin önde gelen karikatür ustalarından Cemal Nadir Güler, karikatürü; resimle, edebiyatın birleştiği sanat olarak tanımlamıştır (Selçuk, 1998: 283). Bu yaklaşım, ülkemizde karikatür sanatının ilk örneklerinin resimsel ve yazıya dayalı olmasından kaynaklanmaktadır. Ancak 20. yüzyılın ortalarında karikatüristler, yazıdan vazgeçerek, abartılı ve felsefi anlatımı sade 
çizgiyle buluşturmuşlardır. Bunun yanı sıra, karikatürde karşımıza çıkan biçim bozma, abartı, grotesk etmenleri ve iki boyutlu tasvir biçimleri ressamların da tercihi haline gelmiştir. Bu şekilde birkaç sanat dalında birden eserler veren çok yönlü sanatçılar ön plana çıkmıştır. Ressam kimliğinin yanı sıra uzun süre Devlet Tiyatroları'nda dekoratörlük yapmış olan Turgut Zaim(1906-1974), Fahir Aksoy'un "Kürdün Meyhanesi" kitabında anlatılan bazı edebiyat insanlarını, karikatürize ederek çizmiştir (Efe, 2007: 104). Turgut Zaim gibi, resim alanındaki üretimi ile tanınmış ama fırçasını ve kalemini karikatür sanatı için de oynatmış diğer ünlü isimler Nuri Abaç (1926-2008), Abidin Dino (1913-1993), Fikret Mualla (1903-1967)ve Güngör Kabakçıŏlu (1933-2011)'dur.

\section{Fotoğrafçllık}

Görsel anlatımda gerçek dünyadan imajların veya nesnelerin fotoğraf düzlemi üzerinde karikatür çizimleriyle birleşerek gündelik hayattan sahnelere yeni bakış açıları getirmesi, özellikle dijital fotoğrafçılığın gelişimi ve internet mecralarında kolayca paylaşılabilmesi açısından çizerlere mizahi anlatımda yeni bir dil kazandırmıştır. 20. Yüzyılda, henüz dijital fotoğrafçlık gelişmemişken, karikatüristler kolaj tekniğini kullanarak gerçek hayattan fotoğraf karelerine çizgi kahramanlarını yerleştirebiliyordu. Karikatür çizimlerinin daha çok bilgisayar programlarında üretimi tercih edildikçe, fotoğraf karelerinin içine sızan karikatürize tipler ve çizgiler çoğalmıştır. Karışık medya tarzındaki bu denemelerde kullanılan fotoğraflar, kimi zaman çizere görsel olarak gerçek hayattan referanslar sunmakta kimi zaman öykü anlatımının mekânsal ve hacimsel özelliklerini gerçeğe yaklaştırmaktadır. Gündelik hayattan objeleri mizahi bir içeriğe göre düzenleyip, bu obje üzerine veya etrafına eklenen çizgilerle ortaya yaratıı fotoğraf kareleri çıkaran sanatçılar ise, bilgisayar ortamında herhangi bir dijital manipülasyona gerek kalmadan direkt somut nesnelerle boya ve mürekkebi tek bakıs açısında buluşturmaktadır. Bu amaç yönünde oluşturulan karikatürlerde yaratıcılık ve mizah, objenin kullanım amacı ile içine yerleștirildiği mizansen, obje üzerindeki ışı-gölge oyunları veya birden fazla objenin ortaya çıkardığı kompozisyon üzerinden sağlanmaktadır. Bu yönde fotoğraf-karikatür üretimleri gerçeklestirmis sanatçılar arasında Lucas Levitan, Hanoch Piven, Vincent Bal, Christoph Niemann, Bülent Üstün (Görsel 3) ve Sadi Tekin örnek gösterilebilir.
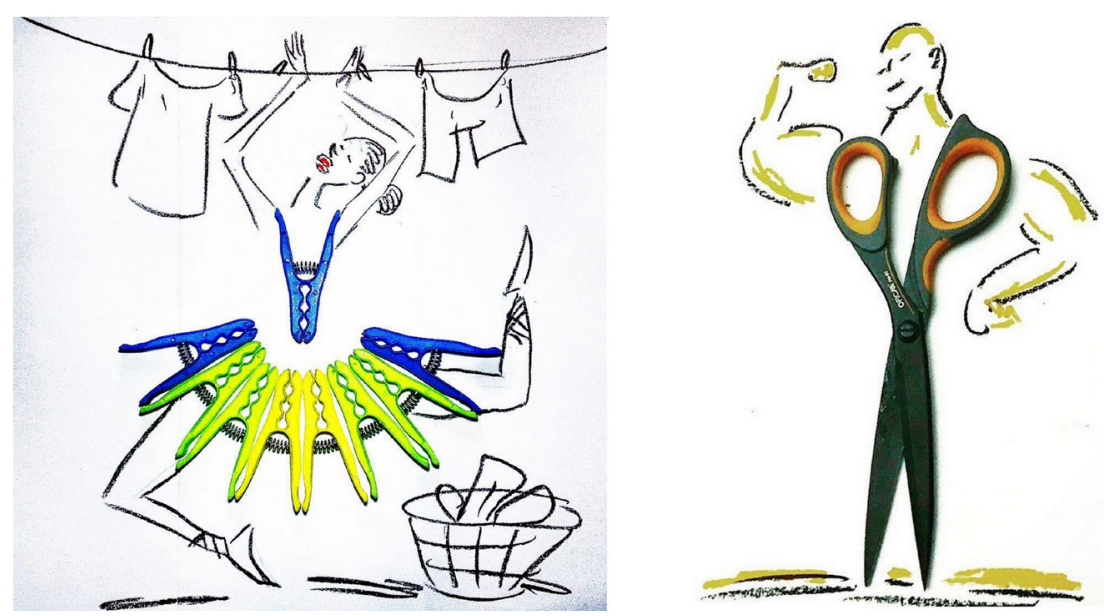

Görsel 3. Bülent Üstün, 'Obje Art’karikatür örnekleri, 2017 (Üstün, 2017)

\section{Sahne Sanatları}

Abartma ve biçim bozma karşılığında mecazi olarak kullanılagelen "karikatürize etmek" deyişi, edebiyat, tiyatro ve sinemada da uygulanabilmektedir. Gölge oyunu ve kukla tasarımları da karikatürleștirilmis tiplerden yararlanmaktadır (Alsaç, 1994: 7). Levent Cantek'in tanımıyla karikatürize etmek; 'basitleştirmek' veya 'belirginleştirmek' olarak herkesin hemen anlayabileceği biçimde bir klişeye dayandırmak anlamında kullanılmaktadır. Bu açıdan mekân ve zaman ruhu da karikatürize edilebilmektedir. Bu yönelişte önemli olan belirlenen amaçtır. Karikatürize etmek, karikatürden çımış gibi görünse de karikatürün ilham kaynağı ya da öncüsü olarak, tiyatro, taklit, gündelik hayattan jestler ve ilişkiler gösterilebilir². Karikatür ile tiyatro arasında kurulan bu bağa örnek olarak Sevda Şener, tiyatro sahnesinde oluşturulacak karakterlerin yazınsal ve devinimsel üretimindeki önemli noktaları açılarken, karikatür biçimlemelerine benzer şu şekilde bir yol göstermiştir: "Sahneye koyuşta da, oyunu yazımında da insanı asal noktalar, asal lekeler olarak görmek, ilişkileri çizgiler ve biçimlerle oluşturmak, koyu, açık vurgularla çeşitleyip zenginleştirmek, dengelemek ve buna ek olarak hareketli bir plastik görünüm sağlamak gerekir" (Şener, 1972: 56). Karikatürde ve sahne üzerinde oluşturulan tipler ve görünümler arasındaki benzerlikler bu şekilde mecazi anlamlarda ortaya çıksa da, bu iki sanat dalı arasında karşıııkı etkileşimlerin önünü açmaktadır.

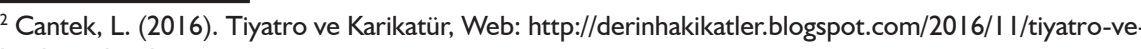
karikatur.html 
Tiyatro tarihinde hareket, mimik ve konuşma biçimi olarak karikatürize bir tip oluşturmanın en meşhur örnekleri, Commedia dell'Arte oyunları ve Moliere $(1622$ - 1673) komedyalarında görülebilmektedir. Güldürüye dayalı Geleneksel Türk Tiyatrosu'nda ise Karagöz ve Ortaoyunu örneklerinde soyut bir dünya betimlemesi ve karikatürize tipler karşımıza çıkmaktadı (Ipşiroğlu, 1992: 214). Abidin Dino, bu türler arasındaki benzer biçimleri şu şekilde değerlendirmiştir:

Karagöz, beyaz perdede komik kişilerin, komik durumlarını canlandırmaktadır. Karikatür, aynı işlevi, dural olarak beyaz kâğıt üzerinde görmektedir. Karagöz'de imge komiği ile durum komikliği birleşiyor. Karikatürde ise surat komikliği ve toplum komikliği bir arada yürütülmüş oluyor. Ortaoyununa bakacak olursak aktörler, yüz hareketleri ve makyajları ile canlı karikatürler yaratıyorlardı. Ortaoyunu, canlı karikatür alanına giriyor, ressamlara örnek yaratıyordu. Dümbüllü'nün can yüz karikatürleri, Leonardo Da Vinci'nin çizgi karikatürlerine çok benzemektedir (Demirel, 2007: 217).

20. yüzyıla doğru, ayrı bir görsel sanat olarak kabul edilmeye başlayan karikatür biçemi, tiyatroda yaratılan sahne karakterlerinin ve mekânlarının görselliğini de şekillendirmeye başladığı örnekler ortaya çıkarmaya başlamıştır. 1896'da Alfred Jarry (1873-1907)'nin kendi yazıp yönettiğ ve bir grotesk tiyatro örneği olan "Kral Übü" (Ubu Roi) isimli oyundaki başkarakter Übü, savaşa susamış bir anti-kahramandır. Bu oyunda gerçekler benzetmeci tiyatro geleneği doğrultusunda göründüğü gibi yansıtılmamış, çarpıtılarak, karikatürleştirilerek, çirkinleştirilerek özüne inilmiştir. Bu, bastırılmış içgüdülerin, korkulu düşlerin sahnede somutlaştı̆̆ ürkütücü bir tiyatrodur. Aynı zamanda gülünç öğeler de barındırmaktadır. Maskeli bir fars havası içinde oynanan oyunda, olayların geçtiği yer soyutlanmıştır. Kral Übü'nün görselliği metnin yazım aşamasında bizzat Alfred Jarry'nin karikatürize çizimleriyle oluşturulmuş ve oyunun daha sonra farklı tarihler ve ülkelerde gerçekleștirilen yapımlarında da bu görsel biçemin korumuştur. Tiyatro karakteri olarak yaratılmış Kral Übü tipi ve tavırlarI, sonrasında karikatürist André François (1915-2005)'nun illüstrasyon çizimlerinde ve ressam Franciszka Themerson (1907-1988)'nun kaleme aldığı bant karikatürlerinde tekrar yaşatıımıştır.Franciszka Themerson aynı zamanda 1964'de Michael Meschke yönetmenliğinde sahnelenen "Kral Übü" temsilinin de sahne ve kukla tasarımlarını gerçekleştirmiş̧ir. Sanatçı bu tasarımında da, bant-karikatürlerinde görülen siyah-beyaz çizgisel estetiği devam ettirmiştir (Görsel 4).

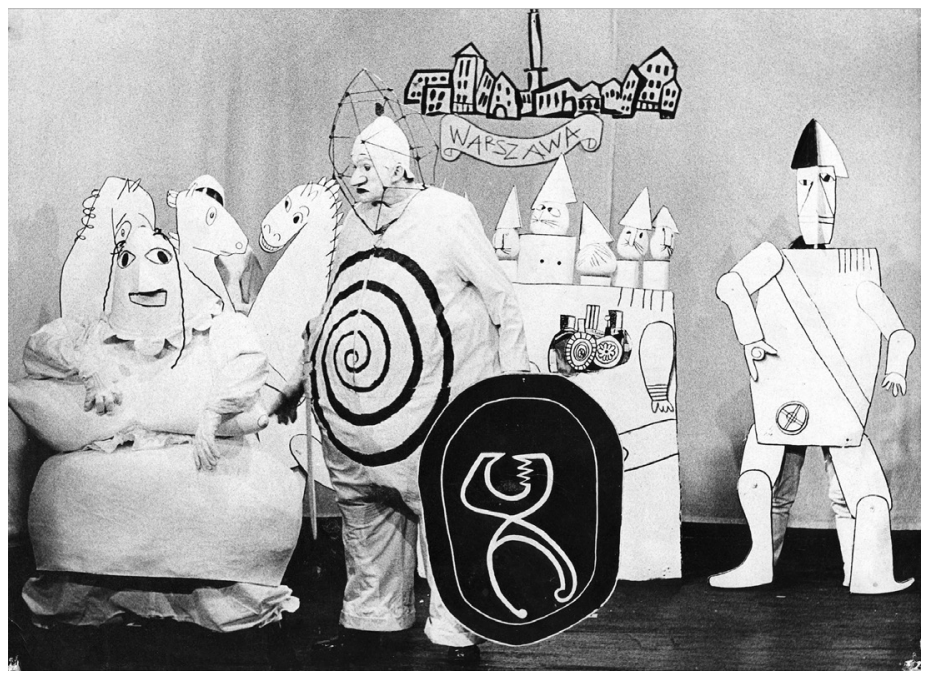

Görsel 4. Marionetteeatern, 'Kral Übü', $1964^{3}$

Orhan Duru'nun “Üzbik Baba" adıyla Türkçe'ye uyarladığı ve Dostlar Tiyatrosu'nun 1988-1989 sezonunda sahnelediği bu oyun, türlü sahne buluşlarıyla renkli bir sirk gösterisine dönüşmüştür. Genco Erkal, Üzbik Baba rolünü kuklamsı, yapay bir tip olarak canlandırmış ve görsel olarak hem tanıdık bildik gelen, hem de yadırgatan garip bir yaratık ortaya çıkarmışır. Genco Erkal, sahne üzerinde bu tipi yorumlarken izlediği yöntemleri şöyle anlatmıştır: “Übü gerçek bir insan değil, bir simge, bir güçtür. Fütüristlerin resimleri, George Grosz'un çizgileri gibi soyut bir şeydir. Bir ses Übü, doğal olmayan bir konuşma biçimi, grotesk çizgilerden oluşan bir görüntü. Rolü hazırlarken gözümün önünde belli çizgiler, biçimler vardı. Özellikle, bu konuda Alfred Jarry'nin kendi çizgileri çok yardımcı oldu(İpşiroğlu, 1992: 271-275).Bu açıdan Jarry'nin karikatür çizgileri, ilk olarak kâğıt üzerinde oyun metniyle beraber iki boyutlu olarak bir tip oluştururken, o tipi canlandıracak oyuncuya da biçimsel olarak kılavuzluk etmiștir. Aynı şekilde kalemini hem absürthikâyeler hem de absürt çizgiler oluşturmak için oynatan isimlerden Roland Topor (1938-1997) ve Friedrich Dürrenmatt (1921-1990)'ın tiyatro oyunlarında da bu etki hissedilmektedir. Bu isimlerin oluşturduğu mekân ve karakterler, eser sahiplerinin hem yazar hem çizer kimlikleri sayesinde, işitsel ve görsel olarak algılanabilmektedir.

20. yüzyıl tiyatrosunda absürt tiyatro ile birlikte politik ve epik tiyatroda da karikatür görselliği gözlemlenmektedir. Politik tiyatronun önde gelen ismi

${ }^{3}$ https://inscriptionjournal.com/2020/06/23/ubu3/ 
Erwin Piscator, 1927'de Yaroslav Hasek'in romanından uyarlanan "Aslan Asker Şvayk" oyununu sahnelemiştir. Bu yapımda saf vatandaş Şvayk'ın savaş serüvenleri sırasında başına gelenler, George Grosz (1893 - 1959)'un karikatürlerinden oluşan çizgi filmkareleri ile sahne üzerinde anlatılmıştır. Grosz'un yarattığı, dönemin politik ve toplumsal yaşamını kişileştiren kemikleşmiş tipler, kimi zaman oyun kişilerinin yerini de almıştır (Candan, 2013: 89). Bu oyun, Piscator Sahnesi'nin en başarılı yapımı olarak anılmaktadır. Romanın oyunlaştııımasında Piscator'un çalışma ekibine Bertolt Brecht de katılmıştır. Brecht'in sonraki dönemde temellerini atacağı epik tiyatro tarzında kaleme aldığı oyunlarının görselliği de, bazı sahneleme örneklerinde karikatür çizgileriyle bağdaşmaktadır. Bunlardan ilki 1988'de Deutches Theater'da Alexander Lang'ın yönettiği "Yuvarlak Kafalılar Sivri Kafalılar" oyunudur. Brecht'in bu oyununda, bir tür korku masalı tanımlamasından yola çıkan yönetmen Lang, oyunu tüyler ürpertici olayların sergilendiği grotesk bir gösteriye dönüştürmüștür. Bu absürt biçem, Volker Pfüller tarafından yapılan kostüm çizimlerindeki karikatürize tiplerde de görülmektedir (İpşiroğlu, 1992: 41). 1964 senesinde ise Giorgio Strehler tarafından yönetilen bir diğer Brecht oyunu olan "Mahagonny Kenti'nin Yükselişi ve Düşüşü", (Görsel 5) Luciano Damiani'nin karikatür çizimlerinden oluşan dekor tasarımı ile sahnelenmiştir (ipşiroğlu, 1992: 31).
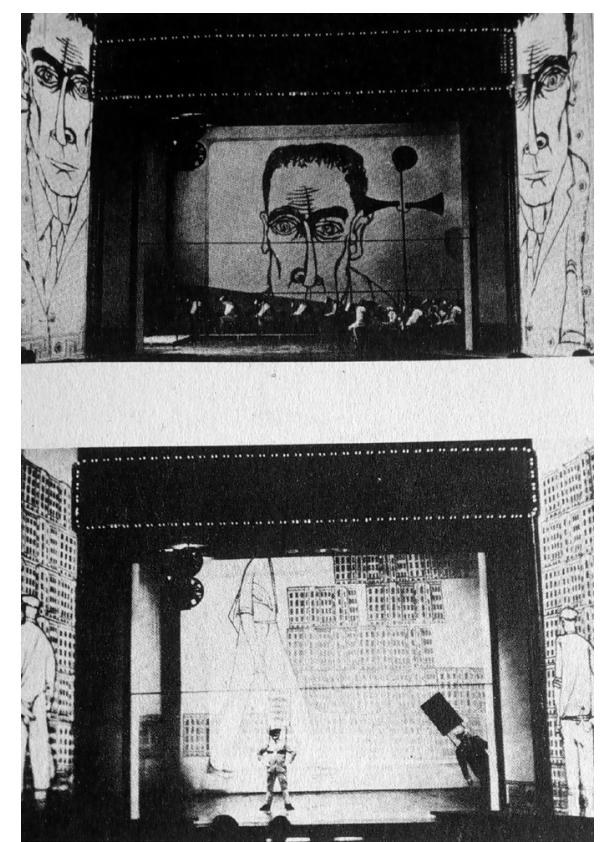

Görsel 5. Teatro Alla Scala, 'Mahagonny Kenti'nin Yükselişi ve Düşüşü', 1964 (ipşiroğlu, 1992: 31).
Türkiye'de ise karikatür çizerliğinin yanı sıra tiyatro eserleri de vermiş isimlere örnek olarak Cemal Nadir Güler (Yüz Karası), Abidin Dino (Kel), Turhan Selçuk (Abdülcanbaz), Behiç Ak (Bina, Tek Kişilik Sehir ve Ayrilık) ve Suav Süalp (íki Kıza Bir Cızbız ve Komser Tulumba) gösterilebilir(Balcıoğlu, 1998: 17).Aynı zamanda tiyatro oyunculuğunun yanı sıra karikatüristliği ile tanınmış isimlere Altan Erbulak, Savaş Dinçel ve Nejat Uygur örnek gösterilebilir.

Yakın tarihten sahne yapımlarına bakacak olursak 1992'den bu yana, karikatür imgelerini grotesk kostümler, giyilebilir mekatronik sistemler ve dijital görüntülerle birleştiren İspanyol enstalasyon ve performans sanatçıs Marcel. li Antunez Roca, iki boyutlu görsel figürlerin hem kendi vücuduyla hem de seyirci etkileşimi ile sahne üzerinde hareketlendirilebilmesini sağlamaktadır. Sanatçının kullandığı dijital ekranlar ve teknolojik araçlar, fiziksel olarak gerçek insan vücudunun, beyaz perde üzerinde görsel olarak karikatürize çizgilerle bütünleşmesini sağlamaktadır. Sahne üzerinde karikatür çizgilerinin fiziksel performansla uyumlu olarak canlandırılmasına opera sanatı üzerinden örnek olarak ise Pier Francesco Maestrini yönetmenliğinde sahnelenen ve Gioacchino Rossini eserleri olan Sevil Berberi (2015)(Görsel 6) ve Reims'e Seyahat (2017) yapımları gösterilebilir. Verona Filarmoni Tiyatrosu'nun sahnelediği bu yapımlarda Joshua Held'in çizimlerini, animasyonlarını gerçekleştirdiği karikatür tiplemeleri ve mekânları, oyuncuların kostüm tasarımları ile bütünleşerek, opera eserlerine modern ve mizahi bir yorum katmıştır4. İlk kez 1933'te Hassard Short yönetiminde sahnelenen "As Thousands Cheer" adlı Broadway müzikali de bu şekilde görselliğini hem fon perdesi çizimleri hem oyuncu maskeleri hem de afiş tasarımında, bant-karikatür ve çizgi-film estetiğiyle bütünleștirmiş bir sahne yapımı örneğidir.

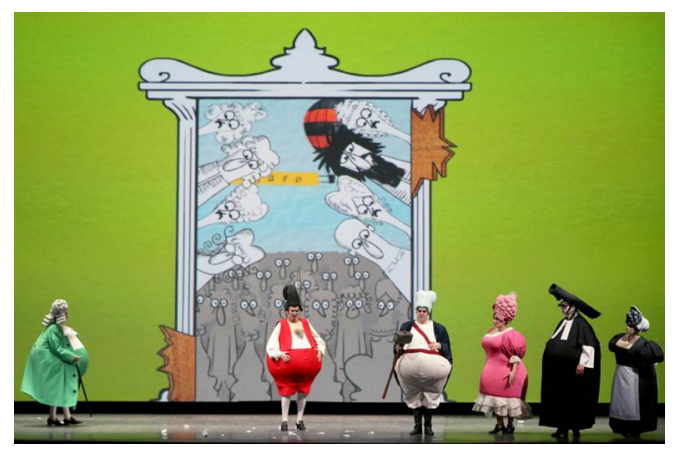

Görsel 6. Verona Filarmoni Tiyatrosu, 'Sevil Berberi' (2015)5

${ }^{4}$ Lodola, F. (May, 2017). Teatro Filarmonico di Verona: II Viaggio A Reims, Web: https:// ierioggidomaniopera.com/2017/05/22/teatro-filarmonico-di-verona-il-viaggio-a-reims/ ${ }^{5} \mathrm{https}: / / \mathrm{www}$.gbopera.it/2015/04/verona-teatro-filarmonico-the-barber-of-seville/ 


\section{Heykel}

Karikatür sanatı sadece kalem, kâğıt, fırça gibi gereçlerin içinde kalmayıp, çeşitli malzemelerle iki boyuttan üçüncü boyuta da geçiş yapmıştır. Yeni teknikler ve gereçlerle beraber yeni anlatım yolları da edinmiştir. Yeni form arayışları içindeki karikatüristler; yontu, kabartma, seramik gibi yaratı alanlarından yararlanmıştır. Ancak bu sanatın kökenleri incelendiğinde Afrika'daki kabilelerin kullandığı fetişler ve maskelerdeki abartı, karikatürün geleneksel temelleri ile benzesmektedir. Hıfzı Topuz'a göre etnik toplulukların maske ve fetiş sanatı ile yontu karikatür örnekleri arasında büyük benzerlikler bulunmaktadır (Topuz, 1986: 53). Bazı kaynaklarda karikatürdeki abartılı ve grotesk biçemin ilk örnekleri olarak üç boyutlu eserler öne çıkarılmaktadır. Ancak hiyeroglif yazı ve tanrıça yontuları, iletişim aracı kimlikleri ve iletileri açıından karikatürden ayrılmaktadır. Ü boyutlu karikatür fikrine daha yakın olarak Danton Jeune'in 1850'lerde yaptığı "Balzac" heykeli daha uygun bir olarak örnek gösterilebilir (Topuz, 1997: 51). Honore Daumier'in "1832'nin Maskeleri"adlı karikatürü ise, yine aynı dönemde yaptığı kilden satirik büstlerin bir nevi eskizleri olarak görülmektedir. Sanatçı bu çalışmaları ile dönemin ünlü siyasetçilerini alaya almış ve bu hicvini ölümsüzleştirmiştir (Şenyapılı, 2003: 120). 20. Yüzyılın ikinci yarısında ise seramik karikatür eserleri gerçekleştirmis ünlü çizerler arasında Giorgio Gabellini, Plantu ve Louise Mitelberg yer almaktadır (Aygün, 2007: 108)

Ülkemizde ise Semih Balcıoğlu(1928-2006), karikatürü sadece beyaz kâğıda çiniyle aktarılan bir sanat olarak görmemiş ve ilk olarak 1965 yılında seramikle üç boyutlu karikatürler gerçekleştirmiştir (Görsel 7)(Çeviker, 1997: 232). 1995 yılında ise karikatürü oyun kâğıtlarına taşıyarak, karikatürün gazete ve dergi sayfalarından tiyatro, dekor, süsleme ve gündelik eşyalar gibi yasamın başka alanlarına karışmasına katkıda bulunmuştur (Şenyapılı, 2000: 57). Sanatçı, seramik karikatüre karşı yaklaşımını şu şekilde aktarmıştır: "Seramik çalışmalarımın karikatürüme çok büyük etkileri olmuştur. Cizdiğim tipleri artık başka türlü görüyor, onları başka türlü ele alıyorum. ilk yıl, iki boyutlu rölyef olarak, iki yıl da üç boyutlu parçalar yaptım"(Balcıoğlu, 2001: 211)

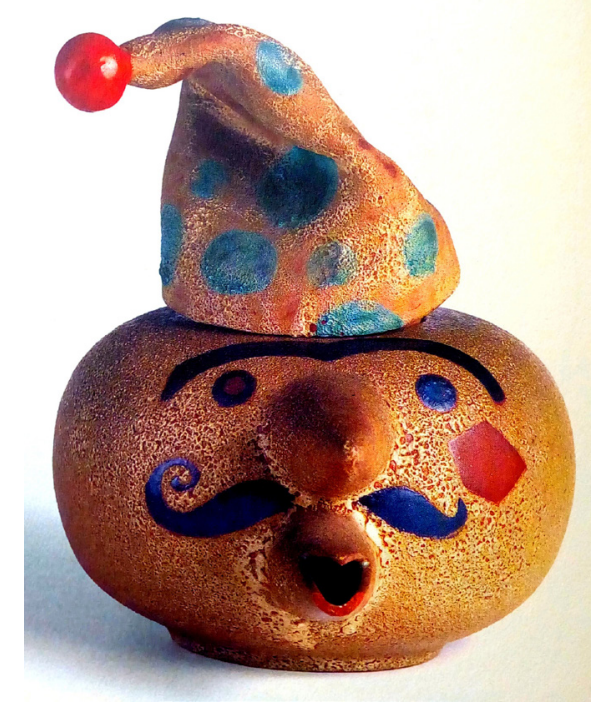

Görsel 7. Semih Balcıŏglu, 'Seramik karikatür’ (Balcıŏlu, 1998: 100).

Türkiye'de üç boyutlu olarak seramik karikatür veya karikatür-heyke çalışmaları, Semih Balcıoğlu'nun eserleriyle sınırlı kalmamıştır. Kamil Masaracı, 2000 yılında Ankara'da sergilediği seramik karikatür çalışmalarını "Seramiki" olarak adlandırmıştır. Oğuz Aral'ın Avanak Avni tipi ise kâğıt yüzeyinden koparak üç boyutlu olarak yaşama katılan karikatür kahramanlardandır (Efe, 2007: 56). Ressam ve karikatürist Mehmet Aslan ise seramik, metal, ahşap gibi çeşitli malzemeleri kullanarak oluşturduğu mizah içerikli objeleri "Satirik Heykeller" olarak tanımlamıştır (Dicle, 1982: 17) 2016 yılında Hasan Fehmi Hızal, "3. Boyutta Turhan Selçuk Çizgi Kahramanları" adlı heykel sergisinde, Turhan Selçuk'un yarattığı "Abdülcanbaz" çizgi öykülerinin başkarakterlerini, üç boyutlu büstler olarak tekrar hayata geçirmiştir

Bulgaristan'da geleneksel olarak gerçekleştirilen Uluslararası Sanatta Mizah ve Yergi Bienali; karikatür, çizim-grafik, resim, heykel, poster ve fotoğraf gibi sanat dallarını kapsamaktadır. Bu bienal kapsamında Sadettin Aygün, 2007 yılında Atilla Özer'in "Karsıllaşma" isimli karikatürünü seramik formunda yorumlayarak heykel ödülünü kazanmıştır. 2009 yılında ise yine Sadettin Aygün ve Atilla Özer'in ortak seramik heykel çalışması

${ }^{6}$ Hızal, D. (2014). Anadolu Aydınlanmasının Öncüleri Anıldı, 03.07.20I4, Web: https://www.aydinlik.com. tr/arsiv/anadolu-aydinlanmasinin-onculeri-anildi\# 
olan "Madalyonlar", heykel ödülüne layık görülmüştür (Aygün, 2013:1314). Karikatür formlarını ve çizimlerini, ürettiği üç boyutlu eserlerle ortaya koyan önemli isimler arasında pop-art sanatçısı Red Groomsda örnek verilebilir. Sanatçının 1975-1979 seneleri arasında sergilediği, heykel-resim olarak tanımladığı ve karikatürize, satirik, renkli sahneler ortaya çıkardığı eserler, hem iç mekân hem de dış mekânlarda sergilenebilecek ölçekte üretilmiştir. 1978 yılında Ankara Sanatseverler Derneği'nde Türk Karikatürcüler Derneği'nce düzenlenmiş "Çizivizyon" karikatür sergisi kapsamında Nezih Danyal'ın, çizgiyle anlatım yerine bir televizyon alıcısı üzerine yapıştırdığı "Yazısız" etiketiyle yaptığı çalışma, üç boyutlu karikatür örnekleri arasında değerlendirilmektedir. Bir enstalasyon çalışması olarak sergilenen eserin sergileme öncesi ve sonrasında geçirdiği değişim ise sanatçının sonrasında kağıda döktüğü çizimiyle kalııı bir karikatüre dönüşmüştür (Şenyapilı, 2003: 196).

20. Yüzyılın ilk yarısında karikatür dilini, çeşitli mizahi icatlar tasarlamak ve üretmek üzere kullanmış çizerler olarak Rube Goldberg (1883 - 1970) ve W. Heath Robinson (1872 -1944), (Görsel 8) karikatür çizgileri ile mekanik endüstriyel tasarım düšüncelerini buluşturan örnekler ortaya çıkarmışıır. Sonrasında 1975 yılında Gırgır Dergisi çizerlerinden İrfan Sayarise, "Porof Zihni Sinir" tipini yaratmış ve bu tipleme üzerinde karikatür-heykeller üretmiştir. Sahne ve Görüntü Sanatları eğitimi görmüş olan Sayar, yarattığı "Porof Zihni Sinir" karikatür serisi ile mekanik tasarım anlayışını hem kağıt üstünde hem de somut objeler üzerinden mizahi bir dille buluşturmaya devam etmiştir (Balcıoğlu, 1998: 222).

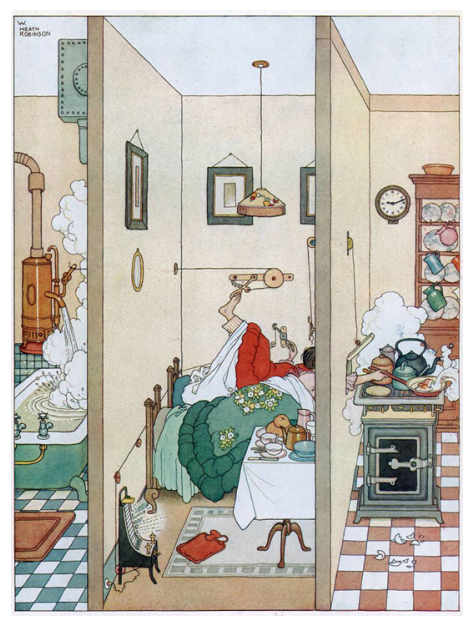

Görsel 8. W. Heath Robinson, An Ideal Home: Bedroom Comfort, $1936^{7}$

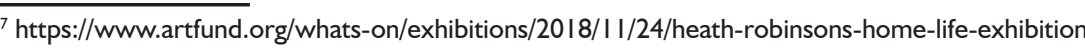

2000'li yılların başında yayınlanmaya başlamış Penguen (2002) ve Uykusuz (2007) mizah dergilerinin çizerlerinden Emrah Ablak, Cem Dinlenmiş, IItem Dilek, Erdil Yaşaroğlu, Gürcan Yurt, Selçuk Erdem, Memo Tembelçizer ve Ersin Karabulut da X-İst'de gerçekleştirdikleri "Çirkin" adlı sergi ile heykel, resim, seramik, illüstrasyon gibi farklı sanat disiplinlerini mizah ve karikatür ortak paydasında buluşturmuşlardır ${ }^{8}$. Bu karma sergide, karikatür çizgi tarzları eserlerinin yer aldığı mizah dergilerde görülen sanatçıların, kendilerine has üsluplarını çeşitli plastik sanatlarda da ortaya koyduğu gözlemlenmektedir. Penguen mizah dergisi kurucularından karikatürist Erdil Yaşaroğlu'nun, karikatür çizgisini farklı formda ele aldığı bir diğer çalışması ise, dünyanın en büyük karikatürü olarak Guinness Rekorlar Kitabı'na giren çizimidir. Bu projede tasarım ve fikir bir isimden çıksa da, 13 saatlik çalışmayla 10.952,050 metre kare büyüklüğünde bir karikatür çiziminin oluşturulması bir ekip çalışmasına dönüşmüştür. Mürekkep yerine beyaz boya ve kâğıt yerine toprak zemin kullanılarak karikatür çizimi, bir arazi sanat olarak ele alınmış ve uygulanmışıı ${ }^{9}$. Sanatçının aynı zamanda 2019 yılında mekana özgü enstalasyon ve heykel sergisi olan "Oyun" da, sergilemenin yer aldığı mekanın açık ve kapalı alanları farklı düzlemlerde ve katmanlarda kullanılmıştır. Erdil Yaşaroğlu'nun bu eserleri, karikatür çiziminde kullandığı form ve espriler, üç boyutlu eserler aracılığılla farklı bir üslupta izleyici ile buluşmuştur.

\section{Sinema}

Karikatür sanatı altın çağını 20. yüzyılda yaşamıştı. Sinema, çizgi öykülerin hareketlendirilmesi, kısa ve uzun metrajlı filmler yapılmasıyla karikatür küreselleşmiştir. Komedi filmlerinde görüntü öğesi ilk sırada olmasına karşın, hareket ve söz öğeleri durumu pekiştirmektedir. Sinemanın ortaya çııısı ile beraber hareket eden karikatürler şeklinde oluşan çizgi film, yeni bir mizah türü olarak doğmustur (Balcıoğlu ve Öngören, 1973: 33).Canlandırma sineması ile karikatür arasındaki ortak iki önemli etmen, mizah ve deforme edilmiş çizgidir. Canlandırma filmi hangi teknikle yapılırsa yapıııı deformasyon varsa, karikatürle orada ilişki başlıyor demektir (Çeviker, 1997: 211). Garfield, Snoopy, Popeye, Hasbi Tembeler gibi dünyaca ünlü çizgi film karakterlerinin hikâyeleri, ilk olarak bant karikatür formuyla basılı yayın için çizilirken, daha sonra çizgi film formatına dönüşmüştür (Şenyapılı, 2000: 58). Pink Floyd grubunun şarkılarından oluşan "The Wall" filminin animasyonlarını çizen Gerald Scarfe ve dünyaca ünlü İngiliz mizah topluluğu Monty Python'ın filmlerinde kullanılan animasyonları çizmiş Terry

Özer, I. (2016). "Ne Çirkin Bir Kedi!", https://irmakozer.com/2016/I2/07/ne-cirkin-bir-kedi/ 9 Apaydın, B. (20I2). Erdil Yaşaroğlu’ndan Dünyanın En Büyük Karikatürü, Web: http://sosyalmedya.co/ erdil-yasaroglu-samsung-karikatur/ 
Gilliam, animasyon anlatımında karikatür üslubunu benimsemiş sanatçılardandır (Gilliam, 2016: 118).

Türkiye'de karikatür çizgilerinin hareketlendirilmesine yönelik çalışmalar 1945 yılında Cemal Nadir Güler'in, "Amcabey" karakterini çizgi filme dönüştürme adına yaklaşık 600 çizimden oluşan denemesiyle başlamıştır. Ancak çizer, teknik zorluklardan ötürü bu çalışmasını tamamlayamadan vazgeçmek zorunda kalmıştır (Atay ve Akşit, 2008: 387-388). ileriki dönemlerde karikatüristlerin hareketli anlatıma ilgileri devam etmiş ve çizgi film alanında üretkenliklerini açığa çıkarmışlardır. Oğuz Aral (1936-2004)'ın kurduğu "Canlı Karikatür Stüdyosu", başarılı çizgi film örneklerine imza atmıştır. Stüdyonun 1966 yapımı altı dakikalık "Direklerarası" adlı kısa filmi, büyük tuluat ustası İsmail Dümbüllü'nün de katkısıyla, belgesel tarzında çekilmiştir. 1969 yllında ise bu stüdyonun ürettiği "Nasreddin Hoca" filmi gösterime sunulmuştur. Çizgi filmlerdeki karakterleri Oğuz Aral çizmiş, çoğaltmaları da yine karikatür çizerleri olan Eflatun Nuri ile Tekin Aral yapmış, animasyon kısmını Ferruh Doğan işlemiştir (Atay ve Akşit, 2008: 118). Döneminin önde gelen karikatüristlerinden Tonguç Yaşar ise, 1969 yılında "Amentü Gemisi Nasıl Yürüdü" adlı üç dakikalık kısa animasyon filmi ile hat sanatı formalarını kullanarak mizahi mizansenler yaratmıstır.

Dostlar Tiyatrosu için "Aslan Asker Şvayk" ve "Zemberek" adlı oyunlarda kullanılmak üzere, reel filmler hazırlamış olan Tan Oral, 1970 senesinde hazırladığı "Sansür" isimli animasyon filmi (Görsel 9) ile TRT Kültür Sanat ve Bilim Odülleri'nde 16 mm'de Büyük Öülü kazanmıştır. Bu animasyondaki çizgi film anlatımı ve çizgi özellikleri, Tan Oral'ın karikatür üslubunun daha sade bir görsel örneğini sunmaktadır (Çeviker, 1997: 261).

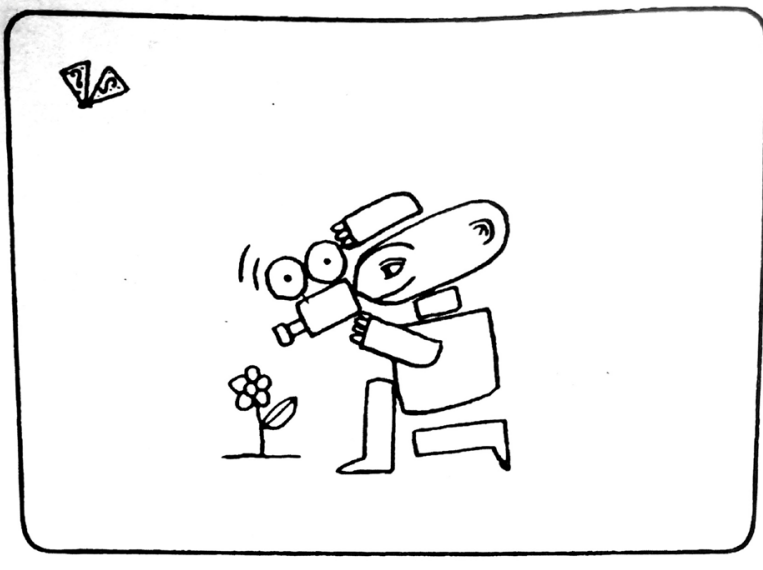

Görsel 9. Tan Oral, ‘Sansür’ kısa filminden kare, 1970 (Çeviker, 1997: 260) 1990'ların sonlarına doğru gazetelerde siyasi gündemi ve insan ilişkilerini konu alan bant karikatürler de, sonraki dönemlerde animasyon dilini kullanmaya başlamıştır. Salih Memecan'ın bant karikatür olarak çizdiği “Bizim City" serisi, sonrasında televizyonda canlı karikatür programı olarak hayata geçmiştir (Koloğlu, 2005: 331). Aynı zamanda çizerin 1991 yılında yarattığı "Sizinkiler" adlı çizgi serilerindeki karikatür karakterlerinin maceraları, 2006 yılında Beşiktaş Kültür Merkezi tarafından çocuk tiyatrosu olarak sahnelenmistir ${ }^{10}$. Piyale Madra'nın ise Milliyet ve Yeniyüzyıl gazetelerinde çizdiği "Piknik" ile "Âdemler ve Havvalar" adlı bant karikatürleri önce Türkçe ve İngilizce olarak kitaplaştırılmış daha sonra çizgi film haline getirilmiştir(Balcıoğlu, 2003:210).

Çeşitli gazete ve mizah dergisi sayfalarında çizgilerle yaratılmış karikatür tiplemeleri ve hikâyeleri zaman zaman sinema perdesinde, televizyon ekranlarında ve tiyatro sahnesinde yeniden hayat bulmuştur. Bu şekilde oyuncular tarafından canlandırılan iki boyutlu karikatür tiplemelerine yeni bir bakış açısılla boyut kazandırımıştır. Sezgin Burak'ın bant-karikatürleri olan Bizimkiler'de yer alan "Hüdaverdi" tiplemesi sinemaya uyarlanmış örneklerinden biridir. Televizyon ekranlarında dizi formatında yer almış karikatür öykülere ise Özden Öğrük'ten "Çılgın Bediş" (1996), Atilla Atalay'dan "Sıdıka" (1997) ve Serkan Yılmaz'dan "Dudullu Postası" (2018) örnek gösterilebilir. Turhan Selçuk'un yarattığı "Abdülcanbaz" serisi ise aynı isimle tiyatro metnine dönüştürülerek Dostlar Tiyatrosu ve Devlet Tiyatroları tarafından sahnelenmiş ve bu öykülerdeki tiplemelerin çizgisel karakterizasyonları sahne üzerinde muhafaza edilerek canlandırılmıştır. Bu yapımlar doğrultusunda karikatür olarak biçimlendirilmiş tiplemelerin ve öyküleştirilmiş olayların zaman ve harekete dayalı anlatı türlerine de ilham olduğu görülmektedir. Karikatür çizimlerinin hareketlendirilmesi ve film formatına dönüştürülmesine yönelik güncel bir örnek olarak ise karikatürist Emrah Ablak'ın 2006 yılında üretmeye başladığı "karikafilm" tasarımları farklı bir canlandırma tekniği sunmaktadır. Geleneksel iki boyutlu animasyon üretiminde görülen, sabit bir kadraj içerisine senkronize olarak akıcı bir canlandırma sağlayacak çizimlerin oluşturulması tekniği mevcuttur. Bu teknik sonrasında karikatür temelli birçok çizgi film örneğinin de benimsediği ve uyguladığı teknik olmuştur. Karikafilm örneklerinde ise Emrah Ablak, kâğıt üzerinde işitsel bir anlatıya veya içeriğe uyumlu olarak storyboard mantığılla kare kare tasarladığı karikatür sahneleri içerisinde kamerasıyla dolaşmaktadır. Bu yöntemle canlandırma, kamera hareketiyle sağlanmakta ve karikatür kareleri arasındaki geçişler işitsel içeriğin akışına göre sağlanmaktadır.

${ }^{10}$ Inceoğlu, D. (2006). 100 bin Çocuk İ̧in Tiyatro, 14.04.2006, Web: http://www.hurriyet.com.tr/100bin-cocuk-icin-tiyatro-4252627 


\section{Sonuç}

Görsel iletişim biçimi olarak karikatür, eleştirel yapısı, mizahi yaklaşımı ve abartıı hatlar içermesi bakımından hem gerçek hem de mecazi anlamıyla farklı alanlarda kullanılabilen bir tanımdır. Karikatür sanatında çizgisel, yalın bir görsel dil ve hızı anlaşııır bir ifade biçimi tercih edilmektedir. Bu anlatı biçimi kimi zaman sadece eğlence amacıyla kahkaha yaratmak için kullanilırken kimi zaman ise eleştiri yüklü bir dille buruk bir gülme yaratmak için kullanılmaktadır. Bu nedenle içerik ve biçim açısından zamanla kendi içerisinde türlere ayrılan karikatür sanatı, içerdiği abartı ve deformasyon kullanımı nedeniyle sözel anlatımda da bir ifade şekline dönüşmüştür. Hangi türde olursa olsun karikatürün kimlikleşen iletişim dili, belli başı biçim özellikleriyle şekillenmiştir. Böylece yalnı çizgiyle oluşturulan grafiksel bir yapıyla sınırlı kalmayarak, insan, olay veya mekân tanımlarında da sıfat olarak kullanılagelmiştir. Böylesine geniş bir çeşitliliğe sahip karikatür tanımının, farklı sanat dallarıyla iletişimi ve etkileşimi olağandır. Temelinde sade çizgi olan karikatür, zamanla farklı formlara bürünerek biçimini zenginleştirmiş ve yaşamaya devam etmiştir. Çeşitli anlatım biçimlerinde kendini göstererek kullanıldığı alanlarda da mizahi bir etki yaratmıştır.

Karikatür sanatının, bir anlatım ve yorumlama biçimi olarak çeşitli sanat dallarında farklı formlarla ve yöntemlerle kullanılması, bu sanatın görsel diline zenginlik katmıştır. Karikatürün oluşturulmasında tercih edilen yaklaşımlar sadece görsel anlatımla sınırlı kalmayıp, sözel, yazınsal ve devinimsel sanatlarda da kendini göstermiştir. Aynı zamanda karikatürlerin iki boyutlu üretimine ek olarak, üçüncü boyut kazandıran örnekler, bu sanatın köklerini daha eski çağlara uzandıracak yaklaşımları doğurmuştur. Bu nedenle karikatürize etme tabiri, birçok sanat ve tasarım alanında farkı yollarla ele alınmıştır. Zamanla gelişen teknolojilerin sanatsal anlamda görsel anlatıma sağladığı katkılar, karikatüristlerin de yenilikçi tarzlarda eserler üretmelerini sağlamaktadır. Disiplinler arası fikir geçişlerinde sağlanacak görsel uyum, karikatür gibi yalın ve vurucu bir iletişim biçiminde daha pratik bir şekilde elde edilebilmektedir. Eğlenceli ve sade görselliğinin yanında, içerik olarak eleştirel ve aykırı bir ton da barındıran karikatür sanatı, bu nedenle pek çok sanatçının zaman zaman kullandığı bir biçem haline gelmiştir. 


\section{Kaynakça}

Acar, S. (1979). Karikatür ve Tiyatro, Oyun Dergisi, I0, II.

Alsaç, Ü. (1994). Türkiye'de Karikatür, Çizgi Roman ve Çizgi Film, İstanbul: İletişim Yay. Atay, K. ve Akşit, K. (2008). Mizahın Abisi Oğuz Aral, İstanbul: Doğan Kitap.

Aygün, S. (2007). “Seramik Karikatürler”, Anadolu Sanat Dergisi, 18, I07-I I 3.

Aygün, S. (20I3). "Anadolu Üniversitesi Eğitim Karikatürleri Müzesi Seramikleri”, Anadolu Üniversitesi Sanat ve Tasarım Dergisi, 3, 10-23.

Balcıŏlu, S. ve Öngören, F. (1973). 50 Yılın Türk Mizah ve Karikatürü, İstanbul: Türkiye İş Bankası Kültür Yay.

Balcıoğlu, S. (1998). Cumhuriyet'in 75. Yılında Türk Karikatürü, İstanbul: Türkiye İş Bankası Kültür Yay.

Balcıoğlu, S. (200I). Önce Çizdim, Sonra Yazdım, İstanbul: Yapı Kredi Yay.

Balcıoğlu, S. (2003). Memleketimden Karikatürcü Manzaraları, İstanbul: Can Yay.

Candan, A. (20I3). Öncü Tiyatro ve Dijital Çağda Gösterim, İstanbul: İstanbul Bilgi Üniversitesi Yay.

Coşar, S. (20I0). “Edebiyatın Karikatürize Halleri”, Turkish Studies, 2 (5), 688-734.

Çeviker, T. (1997). Karikatür Üzerine Yazılar, İstanbul: İris Yay.

Demirel, S. (2007). Abidin Dino Özel Koleksiyon, İstanbul: Yapı Kredi Yay.

Dicle, O. (Mayıs, 1982). Gülmecenin Üç Boyutuna Doğru: Mehmet Aslan ve Heykelleri, Yarın Aylık Sanat ve Edebiyat Dergisi, Ankara: Sanem Matbaaclık, 9, I7-I8.

Efe, H. (2007). Görsel Metinden Yazınsal Metne Metinler arası Illişki - Karikatür ve Edebiyat, İzmir: İlya Yayınevi.

Efe, H. (20I3). Karikatürü Düşündüren İnsan, İzmir: Nezih-er Yay.

Fidan, B. (2007). Reklam ve Karikatür, İstanbul: BAMM Yayın Grubu.

Gilliam, T. (2016). Gilliamesk, İstanbul: Alfa Yay.

Girgin, E. Ç. (1985). Genç Ustalar Yanıtlıyor..., Hürriyet Gösteri Dergisi, 5I, 92-97.

İnam, A. (2010). “Ülkemizin Hayatlarına Bir Karikatür Gibi Bakabilen Insanlara İhtiyacı Var..., İzmir Karikatür ve Felsefe Günleri, 2-3.

İpşiroğlu, Z. (1992). Tiyatroda Yeni Arayışlar, İstanbul: Düzlem Yay.
Jovanovic, G.(I 997). Sanatta Karikatür, (ed. Yusuf Eradam ve Deniz Koç) Ankara Karikatür Vakfı Yayınları, 27-29.

Koestler, A. (1 997). “Karikatür ve Yergi” (çev. Özcan Kabakçıŏlu), Güldiken Dergisi, I2, İstanbul: İris Yay., 7-II.

Koloğlu, O. (2005). Türkiye Karikatür Tarihi, İstanbul: Bileşim Yayınevi.

Kurultay Binay, A. ve Peksevgen Sabuncuoğlu, B. (2015). "Reklamlarda Karikatür Kullanımı: Piyale Örneği”, İletişim Kuram ve Araştırma Dergisi, 40, Gazi Üniversites Illetişim Fakültesi Yay., I53-I 74.

Oral, T. (1998). Yaza Çize, İstanbul: İris Yay.

Özer, A. (1997). Sanat ve Karikatür, Sanatta Karikatür (ed. Yusuf Eradam ve Deniz Koç), Ankara Karikatür Vakfı Yayınları, 5 I-53.

Özer, A. (2004). “Karikatür, Popüler Kültür ve Popüler Karikatür”, Bilim ve Aklın Aydınlığında Ĕgitim Dergisi, 57, 246-249.

Poroy, S.(1 997). Karikatürde Grafik, Sanatta Karikatür, (ed. Yusuf Eradam ve Deniz Koç) Ankara Karikatür Vakfı Yayınları, 37-39.

Saydut, A. (2010). Düşüncenin Özgürlüğü Sanatın Özgürlüğüdür, Karikatür ve Felsefe Günleri, (ed. Hasan Efe) Izmir Karikatürcüler Derneği Yay, 5I-79.

Selçuk, T. (1998). Grafik Mizah, İstanbul: İris Yay.

Sipahioğlu, A. (1999). Türk Grafik Mizahı, İzmir: Dokuz Eylül Yay.

Şener, S. (1972). "Çağdaş Türk Tiyatrosunda Insan”, Ankara Üniversitesi Dil ve Tarih, Coğrafya Fakültesi Yay.

Şenyapııı, Ö. (2000). Karikatür ve Illetişim, Ankara: Karikatür Vakfı Yay.

Şenyapılı, Ö. (2003). Neyi, Neden, Nasıl Anlatıyor Karikatür Kim, Niye Çiziyor!?., Ankara: ODTÜ Geliştirme Vakfı Yay.

Topuz, H. (1986). Illetişimde Karikatür ve Toplum, Eskişehir: Anadolu Üniversitesi Basımevi.

Topuz, H. ( 1997). Dünya Karikatürü, İstanbul: İnkılap Kitabevi.

Uçan, B. (20I3). "Türkiye’de Karikatürün Dijital Dönüşümü: Uykusuz Dergisi”, TOJDAC, 3 (3), 4 I-50.

Üstün, B. (20I7). Obje Art, İstanbul: Komik Şeyler Yayınevi.

Yardımcı, İ. (20I0). “Mizah Kavramı ve Sanattaki Yeri”, Uşak Üniversitesi Sosyal Bilimler Dergisi, 6, I-4।. 


\section{Internet Kaynakları}

Apaydın, B. (Ocak, 20I2). Erdil Yaşaroğlu'ndan Dünyanın En Büyük Karikatürü, Web: http://sosyalmedya.co/erdil-yasaroglu-samsung-karikatur/ adresinden I4 Temmuz

2016'da alınmıştır.

Artist of the Day (2018, November). Web: https://visualdiplomacyusa.blogspot. com/2018/ I I/artist-of-day-november-6-jan-lenica.html

Cantek, L. (Kasım, 2016). Tiyatro ve Karikatür, Web: http://derinhakikatler.blogspot. com/2016/I I/tiyatro-ve-karikatur.html adresinden IOMart 202 I'de alınmıştır.

Comerford, J. (April, 20I5). Verona, Teatro Filarmonico: "The Barber of Seville" https://www.gbopera.it/2015/04/verona-teatro-filarmonico-the-barber-of-seville/ adresinden I 3 Şubat 202 I'de alınmıştır.

Hızal, D. (Temmuz, 20I4). Anadolu Aydınlanmasının Öncüleri Anıldı, 03.07.20I4 Web: https://www.aydinlik.com.tr/arsiv/anadolu-aydinlanmasinin-onculeri-anildi\#! adresinden 9 Kasım 2016'da alınmıștır.

İnceoğlu, D. (Nisan, 2006). 100 bin Çocuk İçin Tiyatro, I4.04.2006, Web: http:// www.hurriyet.com.tr/ I 00-bin-cocuk-icin-tiyatro-4252627, adresinden 12 Şubat 2017'de alınmıştır.

Inscrpition (2020, June). Ubu, Web: https://inscriptionjournal.com/2020/06/23/ubu3/

Kalem, A. (Nisan, 2007). Dansta Teknolojik Eğilimler, Web: http://aylinkalem.

blogspot.com.tr/2007/04/marcelli-antunez-roca-trendsetter-jan.html adresinden 22 Kasım 20 I6'da alınmıştır.

Lodola, F. (May, 2017). Teatro Filarmonico di Verona: II Viaggio A Reims, Web: https://ierioggidomaniopera.com/2017/05/22/teatro-filarmonico-di-verona-il-viaggioa-reims/ adresinden 17 Şubat 202 I'de alınmıştır.

Özer, I. (Aralık, 2016). Ne Çirkin Bir Kedi!, https://irmakozer.com/20।6/12/07/necirkin-bir-kedi/ adresinden 20 Ocak 20I7'de alınmıştır.

Robinson, W. H. (1936). 'An Ideal Home: Bedroom Comfort. https://www. artfund.org/whats-on/exhibitions/2018/I I/24/heath-robinsons-home-lifeexhibition,adresinden 22 Şubat 202 I'de alınmıştır. 